Perera T. \& Rathnayake S.

Wayamba Journal of Management 12 (2)

\title{
Continuous Growth through Entrepreneurial Leadership: A Case study on a Packaging Company in Sri Lanka
}

\author{
T. Perera ${ }^{1} \&$ S. Rathnayake ${ }^{2}$ \\ ${ }^{1}$ Stax Inc. \\ Colombo \\ Sri Lanka \\ ${ }^{2}$ Postgraduate Institute of Management \\ University of Sri Jayewardenepura \\ SRI LANKA \\ thilinicp22@gmail.com¹, samantha@ pim.sjp.ac.lk ${ }^{2}$
}

\begin{abstract}
A humble man who pursues high standards in quality establishes one of the most foremost brands in the packaging industry in Sri Lanka. Korean SPA Packaging (Pvt) Ltd exhibits continuous growth over a long period. Continuous growth measures through several factors-the three critical drivers of constant growth identified as entrepreneurial leadership, operational performance, and green practices. The authors referred to indepth research deliberations to explore the three drivers and the outcome and developed a conceptual framework to focus on the case study. The authors conducted ten in-depth interviews and four focus group discussions with a structured interview guide, apart from the secondary sources. The case study findings would help many businesses as executing entrepreneurial leadership is not bound to a particular industry but to any company that seeks more promising returns. The case showcases how leaders drive performance and green practices.
\end{abstract}

Keywords-: Entrepreneurial Leadership, Operational Performance, Green Practices

\section{INTRODUCTION}

Due to many factors such as globalization, sophisticated customers, and deregulation of the market and international trade, the business environment has become a lot more competitive than ever before. Therefore, the concept 'business growth' can frighten the entrepreneurs, business owners, or managers as much as it excites them. Nevertheless, they are aware and act upon the famous mantra in business: 'grow or die'. Therefore, any company, whether from the private sector or public sector, SME or a multinational, has the 'business growth' in their agendas. Different organizations follow different growth patterns. Organizations in diverse industries catering to varying customers under different 
Perera T. \& Rathnayake S.

Wayamba Journal of Management 12 (2)

circumstances will not grow at the same rate. However, organizations with to experience continuous growth, in other words, growth over a more extended period as opposed to short term growth agendas as growth in one period does not necessarily guarantee the growth in the next period.

The packaging industry worldwide experienced strong growth during the past decade due to the expansions into new markets and the shifts in consumer preferences. Further, recent trends such as digital printing, minimalist product packaging, sustainable packaging, vibrant colors and gradients, and the rise in e-commerce reshape the operations of the packaging industry. The experience, expertise, affordable price, and world-class service standards of Sri Lankan package companies deliver some of the best packaging solutions in the world. Korean SPA Packaging (Pvt) Ltd (KSPA hereafter) is a reputed packaging solutions provider in the country and the only packaging solution provider that caters to flexible packaging needs and corrugated packaging needs. With the vision "to become premium packaging solution provider in Sri Lanka," the company is well equipped with state-of-the-art machinery to provide inventive packaging solutions to the market. Being a BOI registered company, its comprehensive range of innovative products has always been the strength when catering to the market's changing needs.

\subsection{The theme of the case}

The theme of this case is "Continuous growth through entrepreneurial leadership." This case seeks to explore how entrepreneurial leadership can contribute to the continuous growth of an organization, along with the organization's operational performance and green practices. Companies, specifically entrepreneurial ventures, face several obstacles arising from internal and external environments in any industry. However, the organization's ability to overcome these obstacles will determine the growth of the organization. In this context, the entrepreneurial spirit in accepting challenges, finding exciting business opportunities, the ability to foresee the future etc., help entrepreneurial ventures to touch the greener pastures even among the modern business dynamics.

\subsection{Objectives of the study}

This case focuses on executing entrepreneurial leadership, driving operational performance, and adopting green practices in business operations. Therefore, the objectives of this are:

i. To explore how KSPA has achieved continuous growth during the last 12 years.

ii. To study the characteristics of entrepreneurial 
leadership in its continuous growth.

iii. To explore whether continuous growth is influenced by entrepreneurial leadership, operational performance, and green practices.

\subsection{Scope of the case}

The scope of the case is continuous growth, and the unit of analysis is Korean SPA Packaging (Pvt) Ltd. Hence, all the departments within KSPA, such as production, marketing, quality, finance, and human resource, stay within the case scope. With the modern challenges in the business world, it is not easy for a company to sustain itself for a long time. This is because success is decided by the amount of profit a company can generate and the level of evolution a company can bring into a country's economy. The amount of contribution a company makes towards society and its environment also plays a greater role in determining its success. Although external challenges such as inflation, exchange rate crises, price fluctuations in raw materials, etc., the company's revenue growth have been steady during the past 12 years. The business accomplishments and the recognition from the society that KSPA has earned throughout its existence prove its success.

\section{LITERATURE REVIEW}

\subsection{Continues growth}

The main objective of any organization is to experience growth over time. Achtenhagen et al. (2010) suggest that if an organization is experiencing growth over a more extended period, those can be considered organizations that share continuous growth. The survival of the organizations has a close relationship to the development of the organizations. However, what entrepreneurs and business owners seek to achieve is continuous growth in the organization. While there are several measurements to measure the development of an organization, the most commonly used size is the growth in sales. According to Fávero et al. (2018), sales growth is of great importance to the organization as it confirms its continued performance and operation. As per Delmar et al. (2003), revenue growth can be affected by the variations and changes in exchange rates and inflation rates.

Organizations can grow in several ways. An organization's growth patterns are related to several factors, such as the demographics of the organization. In addition to the growth in sales, another measurement of organizational development is employment growth (Fadahunsi, 2012). As per Belsito et al. (2018), organizations should acquire new employees to experience growth in the employment base. Further, Lafuente and Rabetino (2011) claim that the organization's administration should also look for ways to retain their employees as retention of employees too adds 
to employment growth. Keeping and acquiring employees is equally important to an organization because employees are the key strengths of an organization that controls the other assets effectively and efficiently. According to Sarlija et al. (2016), growth in terms of assets is also crucial for an organization to experience growth. Eide et al. (2021) mention that a broader customer base and customer demand play an important role in experiencing long-term success and growth.

\subsection{Entrepreneurial leadership}

Conducting business in the current VUCA (Volatile, Uncertain, Complexity and Ambiguity) world is challenging. There are rapid changes in technology, sophisticated customer demands, fierce competition, increased regulations, etc.; organizations need to look for new ways of overcoming the challenges and adapting to the environment to be competitive in the market (Soomro et al., 2019). In this regard, the importance of entrepreneurial leadership is highly anticipated for organizations to ensure long-term survival compared to the past. According to Harrison et al. (2016), entrepreneurial leadership attributes play a crucial role in achieving success in organizations in this rapidly changing business environment. Miller and Friesen (1978) highlight entrepreneurial leaders are willing to take risks associated with resource commitments considering the potential future returns for the organization. According to Bird (1988), entrepreneurial leaders will stay positive and take risks when the organizations face challenges emanating from the external environment. Gaglio (2004) suggests that entrepreneurial leadership is about recognizing new opportunities to meet challenging business environments. An entrepreneur should be able to develop new ideas so that organization can exploit new opportunities.

Entrepreneurial leaders focus on contributing to the organization purely on their capabilities and seek the contribution from their employees to flourish the organization in the future. Stemming from the leadership studies, entrepreneurial leadership shares many common aspects with transformational leadership, highlighting the importance of the leaders evoking the employees to be proactive in achieving organizational goals. Thus, Chihsiang (2015) defines entrepreneurial leadership as a style of leadership that entails creating a visionary scenario for corporate development and managing the resources to achieve those. Chan et al. (2010) discuss that entrepreneurial leadership encompasses achievement motivation to become successful. The achievement motivation can explain the tendency to accept and continue to work on tasks that result in favorable outcomes despite the challenges. At the same time, when leading an 
organization, entrepreneurial leaders should be able to make decisions, manage stress, time pressures, and be conscientious and competitive (Fernald et al., 2005).

\subsection{Operational performance}

The effects of globalization have significantly changed the ways and means of doing business in the modern world. Advancements in technology, ever-changing customer needs, trade agreements, and volatile markets worsen the situation created by globalization. As a result, manufacturing organizations are continuously exposed to pressure to enhance their operational performance and maintain competitiveness. According to Narasimhan and Das (2001), operating performance is strategic dimensions organizations choose to compete over rivals. One such dimension commonly used by scholars is quality (Corbett \& Van Wassenhove, 1993). Depending on the situation and context, quality can perceive from many aspects. Brown (2013) postulates that organizations should provide superior features and functionalities as customers perceive quality.

While quality is a critical metric, an organization needs to know the other dimensions used to measure operational performance. By implementing essential aspects required under these selected dimensions, organizations can gain a competitive advantage, ensuring continuous growth.
Some of the other commonly used measurements of operational performance include cost, delivery, and flexibility (Hallgren \& Olhager, 2009; Jabbour et al., 2013). Organizations focus on reducing costs as a way of improving financial performance. According to Sweeney (1981), organizations can improve cost performance by significantly enhancing their production processes. At the same time, delivery speed ensures the products are available in the market when customers require them. Da Silveira et al. (2013) claim that organizations incorporate ERP systems to improve delivery performance. These measurements are considered the co-competencies in manufacturing organizations; hence, excelling in these enable organizations to outperform their competitors.

\subsection{Green practices}

Increased incidents around global warming, climate change implications, depletion of natural resources, etc., have resulted in the public being more cautious about protecting the environment. Therefore, organizations too cannot escape from adopting environmental protection initiatives and implementing green practices. Moreover, governmental bodies and environmental pressure groups are aggressively monitoring organization's businesses practices to ensure that they do not result in adverse ecological situations. Therefore, the 
importance of adopting green practices by organizations has become more critical than ever. According to Lo and Shiah (2016), green practices define an organization's actions or initiatives to minimize adverse environmental effects. Adopting green practices includes introducing improved or new methods, processes, or systems to reduce environmental pollution by emissions (El- Fadel et al., 2001). Organizations implement such novel processes even if it involves a substantial financial commitment, considering the responsibility towards environmental protection.

Implementing green practices in organizations is a flourishing area of attention. There can be several methods that organizations can choose to implement to minimize the adverse environmental effect. Laosirihongthong et al. (2013) mention that green practices involve pro-active practices such as waste management, energy conservations, opting to suppliers who ensure ecological friendliness in their products, and re-actives procedures such as adhering to regulatory compliances and legislation. Further, Wong (2015) postulates that organizations committed to environmental stewardship incorporate practices such as streamlining suppliers to include ones practicing green initiatives. In this context, implementing green procedures in organizations is the correct thing to do and an essential component in the business.

\subsection{Competition}

Competition is an unavoidable aspect of any business operating in any industry. Peroni and Ferreira (2011) highlight that competition is linked to either aggressive conduct of a current company or the number of firms in the market, ultimately affecting prices and costs of products. Though many people see competition as an adverse business condition, it may not necessarily be the situation. Competition pressures organizations to perform well in the market, ultimately resulting in enhanced financial performance. For example, the competition promotes a company's technical progress, thus investing in many research and development activities (Song \& Wang, 2018). Moreover, competition act as a mechanism that affects managerial decisions and discipline management (Majeed et al., 2018).

Organizations require resources to conduct their operations. Competition occurs due to the scarcity of resources. Bengtsson and Kock (2000) describe competition as the dynamic situation between organizations because of the fundamental conditions that organizations have to depend on, such as acquiring scarce resources. Here, the resources can be tangible such as machinery and buildings, or intangible resources, such as the intellectual capacity of human 
resources. Therefore, competition occurs when actors in a dynamic situation try to gain the advantages that other actors want to achieve under similar conditions during the same period. The essence of this scenario is to eliminate the rivalries in the same industry attracting their customers. Since profit-making is the ultimate goal of for-profit organizations, as Yuan et al. (2019) mention, competition affects ethically prudent decisions. It puts lots of pressure on an organization's costs and benefits.

\section{METHODS}

The case framework has been developed based on a series of primary and secondary data about KSPA. Entrepreneurial leadership, operational performance, and green practices are the three key drivers driving continuous growth, which is significant. The authors have analyzed the past literature about the three drivers and the result to develop this case framework. The competition identified as a moderator. The case framework, which describes the relationship between the drivers, moderator, and the outcome, is illustrated in Figure 1.

The authors have articulated this case study based on a qualitative approach with quantitative data collected from primary and secondary sources. The main data collection instruments for the qualitative aspect of this case study have been in-depth interviews and focused group discussions. In addition, observations made by the authors while visiting the factories on several occasions were also helpful in discovering the grounded reality of the company. The interviewed individual sample comprises a combination of top management and middlelevel managers. Operational level representatives of the company who are from cross-sections were taken for the focus groups discussions. A structured interview guide was used for the interviews and discussions. Further, to depict the company's growth in terms of quantitative aspects, secondary data on the company's performance such as financial statements and reports and presentations done to the external entities have been used.

\section{RESULTS}

\subsection{About Korean SPA Packaging (Pvt) Ltd}

Across the 27 years in the business, KSPA has grown to a company worth a billion rupees. Excellence in quality, passion for perfection, and serving customers' loyalty uplift organizations to a greater level of success. Since the initiation, KSPA has charted a voyage of triumphs and tribulations to arrive at where they are today. The company produces corrugated packaging solutions and flexible packaging solutions and engages in both direct and indirect exports. Top brands such as Maliban biscuits, MAS, Akbar Brothers, etc., rely on KSPA to help them package and protect 
their product when shipping to different corners in the world. Although they were doing well in terms of financial performance, around the 2008/2009 period, the company decided to standardize their processes and comply with international standards to attract more international customers and ensure future growth.

Achieving continuous revenue growth is essential for KSPA to ensure its survival in the market. To experience revenue growth, KSPA had to ensure they were experiencing a boost in sales volume. Back in 1993, KSPA's initial sales were around 200MT 250MT per month in corrugated production. However, the company gradually increased its sales volumes by diversifying its orders to cater to different industries. Initially, the company was only supplying packaging solutions to garment, luggage, and handbag manufacturing companies. The company started manufacturing products to cater to tea, food, other beverages, fisheries, etc. Adopting such strategies, the company increased its corrugated production sales to $750 \mathrm{MT}-800 \mathrm{MT}$ per month by 2010. Figure 2 explains the revenue performance, and Figure 3 demonstrates performance in annual sales volume.

Depending on the variability in the factors of the external environment, the organizations experience fluctuations in their sales performance. In 2011, KSPA had to go through a tough time due to the terrorist bomb attack in the
USA. The company had to struggle to retain their orders from their customers. Nevertheless, with several turnaround strategies, the company could hold its orders and recover from the chaotic situation. Moreover, since KSPA is mainly engaged in the export market, changes in the exchange rate act as a favorable condition instead of a crisis in the business context of KSPA.

Providing the same old product without any modifications hinders the sales growth of any organization. Therefore, KSPA constantly focuses on research and development activities to bring novel products to the market and enhance sales performance.

Without employees, the most treasured assets in an organization, companies can do significantly less. Realizing this fact in the early stage, KSPA focused on developing the employee base. As the company grows, the management team seeks to hire more qualified employees to the office staff. Even ground-level workers acquired more skilled laborers who have completed at least certification courses from authorized institutes such as German Technical College. This way, KSPA ensured that its labor force was fully geared to contribute effectively to its growth. At the same time, retaining employees was also crucial to KSPA. They grasped that an employee could leave organizations due to several factors such as unsatisfying salaries, inadequate incentives, 
colossal workload, and increased stress level, etc. Hence KSPA is fully committed to providing the best to their employees in all possible ways. Figure 4 depicts the employee growth at KSPA.

Over the years, KSPA invested in numerous fixed assets expecting future returns such as increased capacity, increased production volumes, and increased productivity. Also, by acquiring machines with the latest technology, KSPA tries to obtain a competitive advantage over its rivals. Latest machinery ease-out KSPAs attempts to introduce innovative products to the market. In this packaging industry, if a company cannot cater to the changing market needs, that company's survival is at stake. At present, KSPA is fully equipped with the latest machines used to produce slotted, printed, glued, bundled, or stitched corrugated boxes. Further, KSPA has added six more factories since its inception. Figure 5 shows the growth of KSPA's fixed assets.

\subsection{Entrepreneurial leadership}

Organizations generally do not have a steady flow. Yet, entrepreneurs with distinctive leadership characteristics will make a turnaround in companies with their distinct set of qualities and characteristics. Since the initiation of KSPA, the journey to success was never a bed of roses for Mr. Abeyrathne (Chairman), the driving force behind the success of KSPA. His passion for perfection, loyalty to the customer, and commitment to quality enabled him to touch the peaks of excellence by successfully overcoming the everchanging challenges in the business environment. Through his venture, he imposed new standards in the packaging industry which competitors couldn't defeat. The COO of KSPA expresses his views about Mr. Abeyrathne "If Sri Lanka had five more leaders like Mr. Abeyrathne, then the country will be a paradise. He is very innovative and takes timely decisions, not afraid to take risks".

Operating in the industry for more than 25 years, KSPA had to face many challenges. However, Mr. Abeyrathne did not escape from his dream of building a great company thus faced every challenge that came across him with a positive mindset. He took risks associated with touching the international waters and established a wholly-owned subsidiary in the U.K. Even though KSPA was functioning smoothly, Mr. Abeyrathne got a head start. He built a new factory complex to manufacture corrugated products so that when orders are increasing, they can cater to those orders smoothly without worrying about the capacity. When the company wanted a twin extruder machine within a short period to start their new project, he did not waste time doing conventional methods of gathering and analyzing data. Still, he moved forward with the very first machine they found. 
Even with the recent COVID-19 pandemic where the country experienced sudden lockdowns, Mr. Abeyrathne was not prepared to just wait and watch the next steps. He took the initiative, spoke to relevant parties regarding the situation, and ensured that the company was operating, subject to all safety requirements. The company dispatched the customer orders as agreed.

Staying up-to-date about the market needs and being alert about the changes in the business environment is crucial in entrepreneurial ventures as such alertness helps identify the gaps in the market and results in new business opportunities. Mr. Abeyrathne continually expands the KSPA's product portfolio and develops novel products using the same corrugated paper. One such recent experiment yielded successful results in producing a bobbin used to coil hoses about $30 \mathrm{ft}$ long. This product is made entirely of corrugated paper boards and is now being exported to a customer in Australia as direct export. By purchasing an eightcolor flexographic printer, Mr. Abeyrathne attempts to provide value-added products to their customers in the polythene section. He identifies many potential opportunities by closely monitoring what is happening in the packaging industry and other sectors in line with his businesses. In 2018, he invested in Embilipitiya paper mill to manufacture their corrugated paper material and seek the advantages of backward integration.

Entrepreneurs develop plans for the organization to beat the competition in the domain they are operating. As BOI registered company, KSPA can only supply $20 \%$ to the local market, and the rest of $80 \%$ has to be for exports. While maintaining this ratio, they realized that they were losing many local orders from the customers. Mr. Abeyrathne thought analytically and came up with a strategic plan for this situation. In 2016, KSPA established another wholly-owned subsidiary in Sri Lanka, named Korean SPA Printing Solutions (Pvt) Ltd, to cater to the local market. Mr. Abeyrathne's plans for the company have always focused on long-term survival; hence, he acquired sophisticated machines for the new factory complex. The company can now handle a corrugated production with a capacity of $3,000 \mathrm{MT}$ per month.

Giving up was never an option to pass the challenging situations for Mr. Abeyrathne. His attitude when developing a paper pallet from corrugated paper portrays his desire to succeed in challenging environments. He intends to deliver superior service to the customer and perform better than competitors. He builds a fully functional modern laboratory capable of conducting stringent quality tests in line with international standards. The success of Mr. Abeyrathne demonstrates through the number 
of awards that he was able to get hold of for the company. The pinnacle amongst all awards is winning the platinum award for "Sri Lankan Entrepreneur of the year" in 2015. Table 1 represents the list of awards that Mr. Abeyrathne achieved.

Individuals make decisions based on their prior knowledge, expertise, and experiences. Such choices can incorporate a certain level of biasedness to the decision as it can disregard or miss other possible perspectives to the given scenario. Being the chairman of his own business, Mr. Abeyrathne seeks opinions of experts or professional knowledge when deciding on critical judgments. He aims to assimilate different perspectives from different individuals, which can sometimes result in more significant advantages. Also, to perform better than the competitors and stay ahead in the market, Mr. Abeyrathne can make quick decisions that bring value to the company. He does not depend on such lengthy analysis when the prevailing situation in the company is critical and needs urgent remedies.

\subsection{Operational performance}

Despite the fierce competition in the industry, KSPA stands strong among its competitors. The company had to try several operational strategies that enabled it to be competitive and achieve its design. "The prices of our products are considered to be slightly high in the market, but the customer still wants to be with us because of the trust we have built by providing facilities that others don't offer," claims Mr. Abeyrathne. Likewise, the company has carefully selected several strategic dimensions that are hard to match by the competitors in the industry.

KSPA pays special attention to the different features and functionality of their product to address customer requirements. KSPA continuously produces products that meet essential quality dimensions of a corrugated box, such as burst strength, thickness, compression, water resistance, and print quality. Further, they identified gaps in their inspections sheets hence renewed them to keep track of the order processes and customer requirements to ensure that the product was manufactured according to the customer specifics. Also, they provide to get the best raw materials for the production process. KSPA built a glue kitchen where the whole process of producing glue was automated, eliminating inconsistencies present with manual mixing. Further, KSPA got hold of certificates such as ISO 9001, which greatly value the company.

Achieving cost reductions in the production process was also crucial for the company to anticipate high-profit margins. KSPA invested in several capital types of equipment to replace manual work to eliminate unwanted costs and achieve soft 
savings such as increased productivity and efficiencies. They purchased bag cutting units and a semi-automated die-cutting machine that addressed their issues with scrap and reworks. Similarly, using resources to the maximum can result in significant cost savings. The production department at KSPA developed its process to reuse the scrap reels effectively. Moreover, KSPA used innovative methods to get cost savings, such as centralized the steam distribution system.

Having standard mechanisms that reduce machine downtimes is important for KSPA to complete the order and deliver the finished goods to the customer on the agreed date. KSPA installed a motor protection system in the polybag manufacturing section to prevent sudden machine breakdowns due to the high fluctuations in the electricity supply to the machines. Acquiring the benefits of information technology, KSPA invests in an ERP, and later they switch to another, intending to address the issues with the first system.

\subsection{Green practices}

Due to the competition to source resources faster and better than the others, companies worldwide are consuming Earth's natural resources at an alarming phase. Yet, KSPA never forgets environmental stewardship in its journey to success. KSPA makes sure that all of its production processes agree to environmentally friendly guidelines. Through advanced knowledge and experience, KSPA amended many of its business practices to adhere to environmentally friendly conditions.

If a company is practicing energysaving methods to contribute to environmental stewardship, efficient electricity use is vital. KSPA opts to use natural lighting, such as using transparent sheets in the roof but realizing the energy consumption by keeping lights switched on near virtual machines, they replaced CFL bulbs with LED bulbs over time. They replaced the furnace oil boilers with biomass boilers. Realizing process improvements and technological advancements alone cannot control energy savings, KSPA increased employee awareness regarding the company's efforts to save energy.

Hazardous chemical water is a crucial emission from KSPAs manufacturing plants. Despite the financial cost, KSPA built ink purification plants at their factory premises. This plant does a biological treatment to the washup water to bring the $\mathrm{pH}$ level to the standard level. KSPA also has solid waste generated through various production processes. One such hazardous solid waste is the caustics left after the biological treatment to the wash-up water. The company sends them to Holcim (now INSEE), equipped with incinerators that can destroy these materials without leaving behind any particles. 
With the importance placed on environmental considerations, obtaining ISO certification regarding Environmental Management Systems was important to KSPA. Therefore, KSPA gets hold of ISO 14001 EMS certification to show its commitment to making the planet a greener place. Furthermore, KSPA has been careful when selecting the paper suppliers for the corrugated carton production. Therefore, they streamlined their paper suppliers and opted for suppliers with FSC certification so that KSPA too can be responsible for their production. As a result, the company acquires FSC certification. This certification guarantees that the company uses paper materials that are sourced in a $100 \%$ sustainable manner.

\section{DISCUSSION}

\subsection{Achieving continuous growth}

The modern business world entails numerous uncertainties, which present many challenges resulting in several ups and downs. Achtenhagen et al. (2010) argue that if an organization is experiencing growth over a more extended period, those can be considered organizations that share continuous development. Initiated in 1993 and continuing business till today, KSPA experienced steady growth across the years, specifically over the past 12 years. An increase in sales is of great importance to the organization as it confirms continued performance and operation, as argued by Fávero et al. (2018). Through various diplomatic strategies, KSPA anticipated growth in sales and ensured its survival in the business. Delmar et al. (2003) argue that revenue growth is affected by the variations and changes in exchange rates and inflation rates. By focusing on the export rather than the local market, KSPA eliminated the risks associated with the exchange rate crisis and ensured good revenue performance.

Fadahunsi (2012) argues that employment growth is another measurement that indicates growth in the organization. Over the years, KSPA experienced a growth in its employee base. Belsito et al. (2018) argue that organizations should focus on acquiring new employees to experience a growth in employment base. KSPA concentrates on developing new employees who pose required qualifications for the relevant posts and ensuring a good employee base. Moreover, Lafuente and Rabetino (2011) argue that organizations' administration should also look for ways to retain their employees to increase employment growth. By employing practices such as providing three months salary as bonuses, giving incentives for high performers, and employee welfare activities, KSPA ensured that it retains its employees. Sarlija et al. (2016) claim that growth in assets is essential for an 
organization to experience growth. By acquiring new machinery as per requirement and expanding factory area, KSPA anticipated growth in their investments. Eide et al. (2021) argue that a broader customer base and customer demand enable firms to experience long-term success. KSPA acquired many valuable customers such as IKEA to their customer base. Similarly, Amberry - a small venture in Sri Lanka, diversified its business to include curated gift boxes to broaden its customer base. Initially, the company was producing artisan wooden bow ties and cufflinks for men.

\subsection{Entrepreneurial leadership drives continuous growth}

Over 25 years, KSPA has supplied corrugated and flexible packaging solutions to the market as one of the best packaging solution providers in Sri Lanka. Throughout this journey, Mr. Abeyrathne, the owner/ chairman of the company, has been uniquely leading the company demonstrating many entrepreneurial leadership characteristics. Miller and Friesen (1978) argue that entrepreneurial leaders will risk committing considerable resources to opportunities that can/may fail. Mr. Abeyrathne made a substantial financial commitment in 2017 by acquiring land and setting up Factory - 6. Bird (1988) argues that entrepreneurial leaders will lead the organization even during the turbulence situations that arise due to changes in the external environment and bring the organization to a stable point, taking risks associated with it. During the recent chaos that emerged due to the COVID-19 pandemic, Mr. Abeyrathne conducted business without rattling even during the lockdown period taking all the necessary safety measures. Gaglio (2004) argues that entrepreneurial leaders are proactive in identifying opportunities and exploiting them to enhance their performance. Mr. Abeyrathne gets involved in many $\mathrm{R} \& \mathrm{D}$ initiatives and introduces novel products to the market to attract new customers, improving financial performance.

Entrepreneurial leaders create imaginative scenarios and develop strategic plans to achieve their targets for the organization's future (Chi-Hsiang, 2015). Since KSPA is a BOI-registered company, it can only supply $20 \%$ of its production to the local market, restricting potential local customers. Realizing this bottleneck, Mr. Abeyrathne opens a new subsidiary to cater to the demand from a local customer. Chan et al. (2010) argue that entrepreneurial leadership demonstrates achievement motivation to become successful despite the potential challenges. KSPA couldn't find a suitable customer for its new product - the paper pallet. Mr. Abeyrathne wasn't ready to give up on that. Continuous research on the further developments and constant search for potential buyers enable to win one of the famous brands in the 
World - IKEA as their customer for this product. Fernald et al. (2005) argue that entrepreneurial leaders make appropriate decisions managing stress and time pressures. Mr. Abeyrathne made timely decisions about purchasing state-of-art machines when required and ensured smooth production. Likewise, to stand firm amidst the COVID-19 pandemic, a small Sri Lankan entrepreneurial venture in the tourism industry, operating a hotel in the hill country, shifted their businesses and launched Celeste Daily. Celeste Daily is an online marketplace to sell fresh produce in Colombo.

\subsection{Operational performance boosts continuous growth}

In today's dynamic business environment where there are regular changes in customer needs, increased access to the information, frequent updates to the latest technologies, KSPA had to outperform their competitors to sustain itself in the industry. In this expedition, KSPA chooses several strategic dimensions to secure a unique position in the market to ensure better operational performance. Quality is one such demotion that organizations use as their cocompetency, as Corbett and Van Wassenhove (1993) argued. KSPA gives extra attention to their products' quality and has taken all possible actions to deliver a quality product to the market. Explaining how customers perceive quality, Brown (2013) argues that specific attributes of the product, performance of the product, and level of conformance to the specified standards are key focus areas compared against the competitors. KSPA introduced several products with unique attributes, making KSPA the sole supplier of those products to market. Further, KSPA equips with ISO 9001 QMS certification, which proves its commitment to quality.

Cost-effectiveness and delivery lead time are two other dimensions used together with quality to measure operational performance (Hallgren \& Olhager, 2009). KSPA, through different attempts, seeks to improve its cost performance and delivery performance to be competitive in the industry. Sweeney (1981) argues that continued efforts to enhance processes may result in cost reductions. KSPA revamped its steam distribution process, which they used two different boilers at their two plants to use only one boiler. Hence, they were able to enjoy a considerable amount of cost savings. Further, da Silveira et al. (2013) suggest that using the ERP system helps organizations improve their delivery performance. KSPA invested in a comprehensive ERP system called "Axpert" to get more visibility into their operations and improve planning so that they can deliver orders to the customer at the agreed date.

\subsection{Green practices backing to achieve continuous growth}


KSPA geares to support the global efforts to protect Earth's natural resources and commitment to environmental sustainability. KSPA did not desire to achieve success at the expense of ecological stability. Lo and Shiah (2016) define green practices as practices that organizations adopt to minimize the adverse effect on the environment through their facilities. KSPA adopted several practices to reduce, where possible, eliminate adverse effects on the environment when conducting the business. ElFadel et al. (2001) argue that adopting green practices includes introducing improved or new methods, processes, or systems to reduce environmental pollution by emissions. KSPA spent a significant sum of money on building purification plants in their factory premises. The washup water from the factories undergoes a chemical treatment to separate the contaminants from the wash-up water before disposing to the environment. This washup water consists of several hazardous chemicals which harmful to the environment if mixed directly.

KSPA, as responsible traders, was confident that they could do more to minimize the adverse effects on the environment. Laosirihongthong et al. (2013) argue that adopting green practices includes waste management, energy conservations, opting for suppliers who ensure environmental friendliness in their products, adhering to regulatory compliances and legislation, etc. Intending to attach to renewable energy sources, KSPA switched from furnace oil boilers to biomass boilers. Wong (2015) claim that organizations committed to environmental stewardship incorporate green requirements when selecting their suppliers, and it is an integral part of environmental management. KSPA has got hold of FSC certification, and currently, more than $70 \%$ of their corrugated suppliers are FSC certified.

\section{CONCLUSION}

Conclusions for this case study are arrived at based on the three objectives set at the beginning of this case study. These conclusions are particular to this case study and result from the company's gathered primary and secondary data and the observations made during the factory visits.

Through the gathered data, the authors were able to show evidence of how KSPA achieved continuous growth over the last 12 years. One such key evidence is how KSPA made constant profits throughout the period despite all the challenges such as exchange range crisis, inflation, and most importantly, even during the COVID - 19 pandemics, where most companies struggled to survive. At the same time, the amount of assets such as state-ofart machines and land and buildings the company was able to acquire indicates their continuous 
growth. Further, the company's ability to develop the world's foremost brands, such as IKEA, gives enough evidence of how it grew its customer base to ensure continuous revenue. Moreover, due to various best practices, the company also shows growth in its employee base. Primary data highlighted that majority of the employees of the company have been with the company for more than ten years, which is evidence for the retention of existing employees, which ultimately contributes to the growth of the employee base.

The case study mainly discusses the execution of entrepreneurial leadership, which is the key driver of the company's continuous growth. The primary and secondary data gathered provides enough evidence to the characteristics of entrepreneurial leadership practiced by the owner/ chairmen of the company. The chairman was never willing to delay any step that would bring affluence to the company; hence took risks associated with them and worked on strategies to make the impossible possible. Further, he grabbed the opportunities that evolved through the external environment, market knowledge, and innovation without delays so that the company gets the firstmover advantage. He has always had the long-term vision and gathered a supporting cast to take the company to greener pastures. Moreover, he always has a passion for perfection and achievement motivation, further evidenced by the number of prestigious awards. He never delayed any critical decisions that needed to be taken and did not allow biasedness to get carried away.

It was clear that KSPA focused on several dimensions to stand among the competition, which helped boost their operational performance. Through increased focus on improving product features and functionality and research and development activities, KSPA delivered highquality products that customers desire. At the same time, revamping production processes results in cost savings in productions and seeks ways to provide the product to customers at the agreed time. These dimensions helped KSPA to grow continuously.

Further, the company never ignored the environmental considerations while running the business hence adopted many green practices. The data show that the company formed better ways to dispose of their hazardous waste despite costly investments and implemented energy-saving practices. The compliance certifications they were able to get hold of are testimony to their contribution to the environment. Therefore, green rules adopted by KSPA acted as catalysts to achieve continuous growth. These factors discussed here facilitated the authors to accomplish the third objective of the case study.

\subsection{Practical implications}


Rooted in a humble beginning, how KSPA strives to be the most preferred packaging solution provider in the industry is truly an eye-opening success story representing many learning points for entrepreneurial ventures and other businesses. Although the inherent volatility in the current business environment, how the company's leadership effectively demonstrated entrepreneurial qualities to bring the best is an excellent learning point to entrepreneurial businesses. Startups can learn a lot about how the leader took risks with the expectation of favorable returns and how he made strategies to overcome such challenging scenarios envisioning the future. Further, his thirst to find new business opportunities and techniques to make those opportunities a reality illustrate how companies should be diplomatic when conducting businesses.

Many organizations struggle because they cannot identify the critical competitive aspects they should focus on to beat the competition. KSPA carefully selected several dimensions that they should continue to work on to stand solid among the competitors. Its efforts to produce a quality product to the market demonstrate many lessons to the organizations as to why they shouldn't ignore customer requirements and disregard the quality of the product and services they provide. Despite the comparatively high price that KSPA charges, customers still prefer KSPA's products due to the superior quality. At the same time, KSPA's approaches to delivering orders on the date agreed are also a good learning point for any manufacturing organization.

How KSPA ensured environmental stewardship is also an interesting learning point for other organizations in the journey to success. The green practices KSPA adopted reveal how organizations genuinely committed to the environment behave in the industrial world. Despite the costly investments, KSPA built several solutions to address the areas that create adverse environmental effects. Other companies could learn from KSPA and take the same path to treat the environment as adopting green practices played an essential role in the continuous growth experienced by KSPA. 
Perera T. \& Rathnayake S.

Wayamba Journal of Management 12 (2)

APPENDIX

Figure 1: Case framework

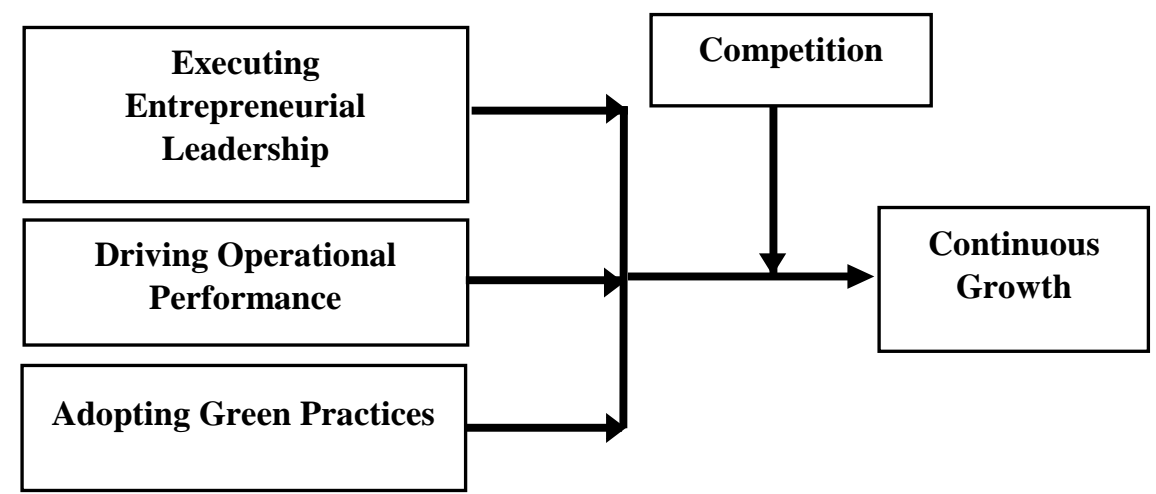

Source: Authors

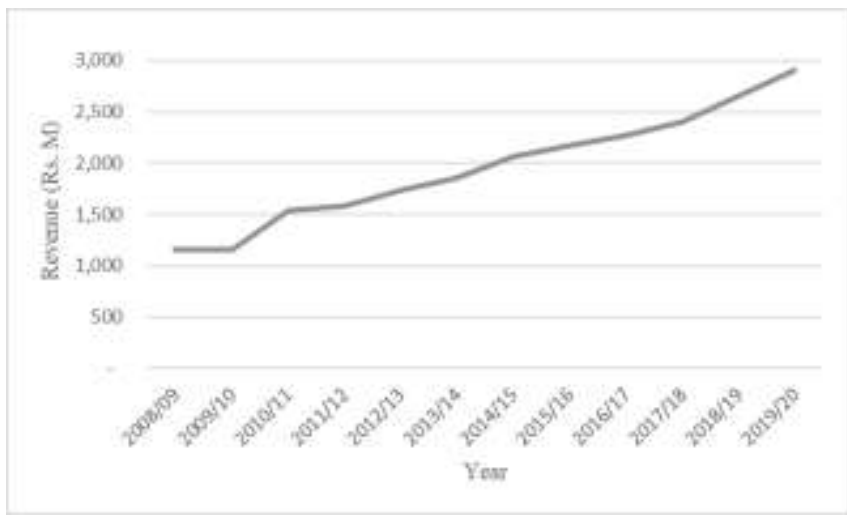

Figure 2: Revenue performance

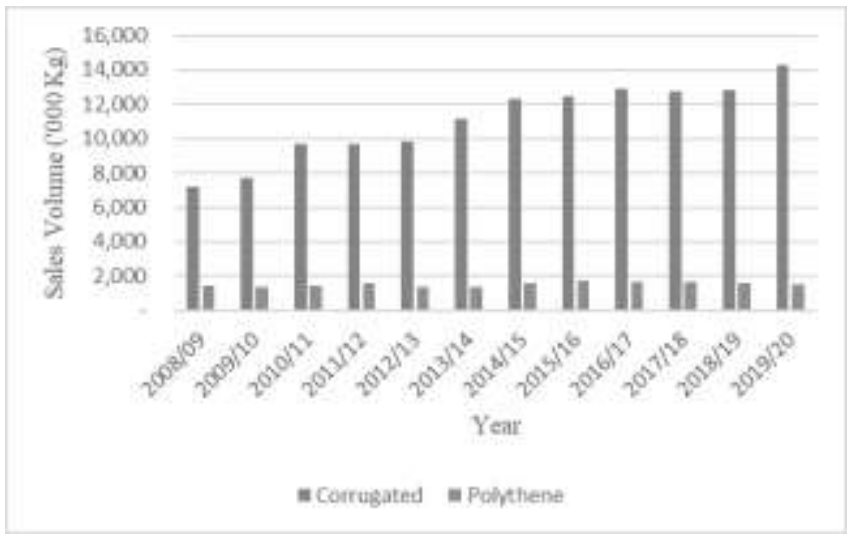

Figure 3: Sales volume performance 
Perera T. \& Rathnayake S.

Wayamba Journal of Management 12 (2)

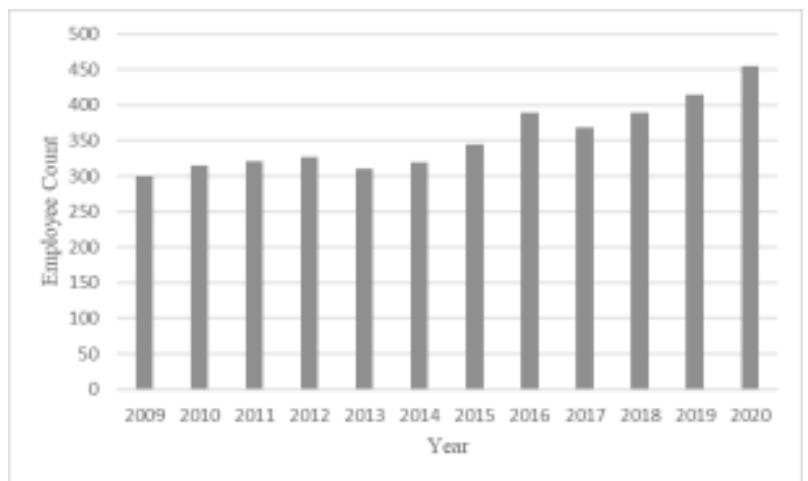

Figure 4: Growth in employee base

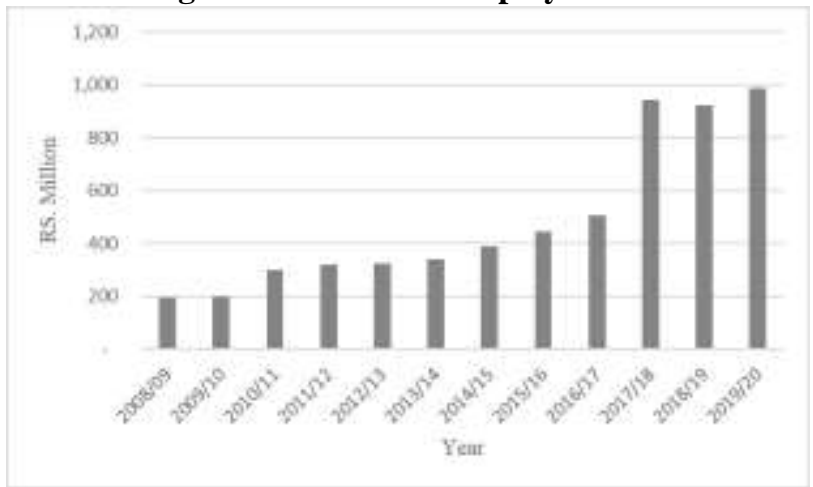

Figure 5: Growth in property plant and equipment

Table 1: Awards received by KSPA

\begin{tabular}{|l|l|}
\hline Year & Award \\
\hline 2006 & $\begin{array}{l}\text { NCE Exports Awards } \\
\text { Organized by National Chamber of Exporters - Sri Lanka }\end{array}$ \\
\hline 2007 & $\begin{array}{l}\text { NCE Exports Awards - Silver } \\
\text { Organized by National Chamber of Exporters - Sri Lanka }\end{array}$ \\
\hline 2008 & $\begin{array}{l}\text { NCE Exports Awards - Silver } \\
\text { Organized by National Chamber of Exporters - Sri Lanka }\end{array}$ \\
\hline 2014 & $\begin{array}{l}\text { Sri Lankan Entrepreneur of the Year - Silver } \\
\text { Organized by FCCISL }\end{array}$ \\
\hline 2014 & $\begin{array}{l}\text { Sri Lankan Entrepreneur of the Year - Gold } \\
\text { Organized by FCCISL }\end{array}$ \\
\hline 2015 & $\begin{array}{l}\text { Sri Lankan Entrepreneur of the Year - Gold } \\
\text { Organized by FCCISL }\end{array}$ \\
\hline 2015 & $\begin{array}{l}\text { Sri Lankan Entrepreneur of the Year - Platinum } \\
\text { Organized by FCCISL }\end{array}$ \\
\hline
\end{tabular}

Source: Company Survey Data 


\section{REFERENCES}

Achtenhagen, L., Naldi, L., \& Melin, L. (2010). Business Growth - Do Practitioners and Scholars Really Talk About the Same Thing? Entrepreneurship Theory and Practice, 34(2), 289-316. $10.1111 / \mathrm{j} .1540-$ 6520.2010 .00376

Belsito, C. A., Reutzel, C. R., \& Collins, J. D. (2018). Human resource executives and post-IPO firm growth. Journal of Organizational Change Management, 31(7), 1401-1418. https://doi.org/10.1108/ JOCM-12-2017-0460

Bengtsson, M.,

\& Kock, S. (2000).

Co- opetition in

business networks - to cooperate and compete simultaneously. Industri al Marketing Management, 29(1), 411- 26.

Bird, B. (1988). Implementing Entrepreneurial Ideas: The Case for Intention. The Academy of Management Review, 13(3), 442 - 453. doi: $10.2307 / 258091$

Brown, A. (2013). Quality: Where have we come from and what can we expect?. The TQM Journal,
25(6),

585-596. https://doi.org/10.1108/ TQM-04-2013-0045

Chan, T. C. K., Ng, K. Y. N., \& Casimir, G. (2010). The diminished effect of psychological empowerment on the self- empowered.

Managing Service Quality: An International Journal, 20(6), 531-543. https://doi.org/10.1108/ 09604521011092875

Chi-hsiang, C. (2015). Effects of shared vision and integrations on entrepreneurial performance: Empirical analyses of 246 new Chinese ventures. Chinese Management Studies, 9(2), 150-175. https://doi.org/10.1108/ CMS-04-2013-0057

Corbett, C., \& Van Wassenhove, L. (1993). Trade-offs? Why trade-offs? Competence and competitiveness in manufacturing strategy. California Management Review, 35(4), 107-122.

Da Silveira, G. J. C., Snider, B., \& Balakrishnan, J. (2013). Compensation- based incentives, ERP and delivery performance: Analysis from 
Perera T. \& Rathnayake S.

Wayamba Journal of Management 12 (2)

production and

improvement

perspectives.

International Journal of

Operations

Production

Management, 33(4), 415-441.

https://doi.org/10.1108/

01443571311307307

Delmar, F., Davidsson, P., \& Gartner, W. B. (2003). Arriving at the highgrowth firm. Journal of Business Venturing, 18(2), 189-216.

Eide, A. E., Moen, Ø., Madsen, T. K., \& Azari, M. J. (2021). Growth aspirations in SMEs: Managerial determinants and organizational outcomes. Journal of Small Business and Enterprise

Development, 28(4), 640-665.

https://doi.org/10.1108/

JSBED-09-2020-0332

El- Fadel, M., Zeinati, M., ElJisr, K., \& Jamali, D. (2001). Industrial waste management in developing countries: The case of Lebanon. Journal of Environmental

Management, 61(1), 281- 300 .

Fadahunsi, A. (2012). The growth of small businesses: Towards a research agenda. American
Journal of Economics and Business Administration, 4(1), 105-115. https://doi.org/10.3844/ ajebasp.2012.105.115

Fávero, L. P. L., Serra, R. G., dos Santos, M. A., \& Brunaldi, E. (2018). Cross-classified multilevel determinants of firm's sales growth in Latin America. International Journal of Emerging Markets, 13(5), 902-924. https://doi.org/10.1108/I JoEM-02-2017-0065

Fernald, L. W. Jr, Solomon, G. T., \& Tarabishy, A. (2005). A new paradigm: Entrepreneurial leadership. Southern Business Review, 30(2), 1-10.

Gaglio, C. M. (2004). The Role of Mental Simulations and Counterfactual

Thinking in the Opportunity

Identification Process. Entrepreneurship Theory and Practice, 28(6), 533-552. doi:10.1111/j.15406520.2004.00063.x

Hallgren, M., \& Olhager, J. (2009).

Flexibility configurations:

Empirical analysis of volume and product mix flexibility. OmegaInternational Journal of Management Science, 
Perera T. \& Rathnayake S.

Wayamba Journal of Management 12 (2)

37(4),

746-756

http://dx.doi.org/10.101

6/j.omega.2008.07.004

Harrison, C., Paul, S., \& Burnard, $\mathrm{K}$.

(2016).

Entrepreneurial

leadership in retail pharmacy: Developing economy perspective. Journal of Workplace Learning, 28(3), 150167.

Jabbour, C. J. C., de Sousa Jabbour, A.

B.

L., Govindan, K., Teixe ira, A. A., \& de Souza Freitas, W. L. (2013). Environmental management and operational performance in automotive companies in Brazil: The role of human resource management and lean manufacturing. Journal of Cleaner Production, 47(1), 129-140.

Lafuente, E., \& Rabetino, R. (2011). Human capital and growth in Romanian small firms. Journal of Small Business and Enterprise Development, 18(1), 7496.

https://doi.org/10.1108/ 14626001111106442

Laosirihongthong, T., Adebanjo, D., \& Choon Tan, K. (2013). Green supply chain management practices and performance. Industrial
Management \& Data Systems, 113(8), 10881109. https://doi.org/10.1108/I MDS-04-2013-0164

Lo, S., M., \& Shiah, Y. A. (2016). Associating the motivation with the practices of firms going green: The moderator role of environmental uncertainty. Supply Chain Management, 21 (4), 485-498. https://doi.org/10.1108/ SCM-05-2015-0184

Majeed, M. A., Yan, C., \& Tauni, M. Z. (2018). How does competition shape managerial decisions? Product market competition and financial statement comparability.

Management Decision, 56(11), 2437-2471. https://doi.org/10.1108/ MD-04-2017-0319

Miller, D., \& Friesen, P. H. (1978). Archetypes of strategy formulation. Management Science, 24(9), 921- 933.

Narasimhan, R., \& Das, A. (2001). The impact of purchasing integration and practices on manufacturing performance. Journal of Operations

Management, 19(5), 593-609. 
Peroni, C., \& Ferreira, I. S. G. (2011). Competition and Innovation in Luxembourg. Journal of Industry, Competition and Trade, 12(1), 93117.

doi:10.1007/s 10842-

011-0101-x

Sarlija, N., Pfeifer, S., Jeger, M., \& Bilandzic, A. (2016). Measuring enterprise growth: Pitfalls and implications. Internatio nal Scholarly and Scientific Research and Innovation, 10(6), 16061613.

Song, M., \& Wang, S. (2018). Market competition, green technology progress and comparative advantages in China. Management Decision, 56(1), 188203.

https://doi.org/10.1108/ MD-04-2017-0375

Soomro,

B.

A., Shah, N., \& Mangi, S. (2019). Factors affecting the entrepreneurial leadership in small- and medium-sized enterprises (SMEs) of Pakistan: An empirical evidence. World
Journal

of

Entrepreneurship,

Management

and

Sustainable

Development, 15(1), 3144. https://doi.org/10.11 08/WJEMSD-05-20180054

Sweeney, G. (1981). Adoption of Cost-Saving Innovations by a Regulated Firm. The American Economic Review, 71(3), 437-447.

Wong, C. Y., Wong, C. W., \& Boon-itt, S. (2015). Integrating environmental management into supply chains: A systematic literature review and theoretical framework. International Journal of Physical Distribution \& Logistics Management, 45(1/2), 43-68. https://doi.org/10.1108/I JPDLM-05-2013-0110

Yuan, J., Zhou, Z., Zhou, N., \& Zhan, G. (2019). Product market competition, market munificence and firms' unethical behavior. Chinese Management Studies, 13(2), 468-488. 